\title{
De arbeidsmarkt voor MBO-schoolverlaters: nu en straks
}

Citation for published version (APA):

van Eijs, P. W. L. J. (2002). De arbeidsmarkt voor MBO-schoolverlaters: nu en straks. Researchcentrum voor Onderwijs en Arbeidsmarkt, Faculteit der Economische Wetenschappen. ROA Reports No. 5 https://doi.org/10.26481/umarep.2002005

Document status and date:

Published: 01/01/2002

DOI:

10.26481/umarep.2002005

Document Version:

Publisher's PDF, also known as Version of record

\section{Please check the document version of this publication:}

- A submitted manuscript is the version of the article upon submission and before peer-review. There can be important differences between the submitted version and the official published version of record.

People interested in the research are advised to contact the author for the final version of the publication, or visit the DOI to the publisher's website.

- The final author version and the galley proof are versions of the publication after peer review.

- The final published version features the final layout of the paper including the volume, issue and page numbers.

Link to publication

\footnotetext{
General rights rights.

- You may freely distribute the URL identifying the publication in the public portal. please follow below link for the End User Agreement:

www.umlib.nl/taverne-license

Take down policy

If you believe that this document breaches copyright please contact us at:

repository@maastrichtuniversity.nl

providing details and we will investigate your claim.
}

Copyright and moral rights for the publications made accessible in the public portal are retained by the authors and/or other copyright owners and it is a condition of accessing publications that users recognise and abide by the legal requirements associated with these

- Users may download and print one copy of any publication from the public portal for the purpose of private study or research.

- You may not further distribute the material or use it for any profit-making activity or commercial gain

If the publication is distributed under the terms of Article $25 \mathrm{fa}$ of the Dutch Copyright Act, indicated by the "Taverne" license above, 


\title{
De arbeidsmarkt voor MBO-schoolverlaters: nu en straks
}

\author{
ROA-R-2002/5
}

Patrick van Eijs

\section{Researchcentrum voor Onderwijs en Arbeidsmarkt}

Faculteit der Economische Wetenschappen en Bedrijfskunde Universiteit Maastricht

Maastricht, april 2002 
ISBN 90-5321-331-7

Sec02.051.doc 
Inhoud

Bladzijde

Voorwoord

Resumé

iii

1 Inleiding 1

2 Na de MBO-opleiding 3

3 MBO'ers aan het werk 9

4 Zit de MBO'er op zijn plek? $\quad 15$

5 De arbeidsmarkt voor MBO'ers tot $2006 \quad 21$

Bijlage: niveaus en leerwegen in het MBO 25 



\section{Voorwoord}

De Bve Raad is de brancheorganisatie van alle instellingen voor het beroepsonderwijs en de volwassenen educatie, in het kort bve. Deze onderwijssector heeft ca 600.000 deelnemers en 43.000 werknemers. De sector staat centraal in de samenleving, heeft niet alleen tot taak deelnemers op te leiden tot goed gekwalificeerde werknemers, maar ook toe te rusten met maatschappelijk relevante competenties en de basis voor een leven lang leren. Als branche is het belangrijk om zicht te hebben op de resultaten van de inspanningen van de bve instellingen. Met deze intentie heeft de Bve Raad opdracht gegeven tot deze publicatie gebaseerd op gedegen onderzoek, waarin specifiek de toeleiding naar de arbeidsmarkt centraal staat.

De Bve Raad heeft de opdracht voor het onderzoek, dat voor een belangrijk deel put uit cijfers uit het RUBS-onderzoek, gericht op de bestemming van de MBO-schoolverlater. Maar ook de maatschappelijke positie van de MBO-ers, de werkloosheid en het doorstuderen zijn aspecten die ruim aandacht krijgen.

Verder komt het zoekgedrag naar een baan aan de orde. De resultaten hebben betrekking op allerlei aspecten van de loopbaan na het afstuderen. Ook komen de verschillen tussen de beroepsopleidende en de beroepsbegeleidende leerweg aan bod. Er wordt nader ingegaan op de huidige arbeidsmarktpositie van respondenten met resultaten over het dienstverband en de mogelijke redenen om van baan te wisselen. Ten slotte gaat de onderzoeker in op de structurele arbeidsmarktpositie en het toekomstig arbeidsmarktperspectief tot 2006.

Het volledige rapport "De arbeidsmarkt voor MBO-schoolverlaters: nu en straks" is te lezen en te downloaden via de website van de Bve Raad: www.bveraad.nl. Bovendien zal er in het magazine Bve Radius, mei 2002, aan het onderzoek aandacht worden geschonken.

Ik hoop dat $\mathrm{u}$ dit onderzoek met belangstelling zult lezen.

ir. A.J.M. Vollebregt

directeur Bve Raad 



\section{Resumé}

Het middelbaar beroepsonderwijs speelt een belangrijke rol in het Nederlandse onderwijssysteem. Ongeveer de helft van de Nederlandse beroepsbevolking is middelbaar opgeleid. Het aandeel MBO'ers onder de huidige schoolverlaters is zelfs nog groter. Bovendien, en zeker niet in de laatste plaats, vervult het MBO een belangrijke rol in de voorbereiding op het hoger beroepsonderwijs. Een aanzienlijk deel van de HBO'ers zijn doorstromers vanuit het MBO. Onderzoek laat zien dat het middelbaar beroepsonderwijs een sleutelrol vervult in de economische ontwikkeling. In het licht van dit belang van het middelbaar beroepsonderwijs, moet er een goede aansluiting tussen onderwijs en arbeidsmarkt zijn en moet de transitie van school naar werk goed verlopen. Deze rapportage belicht de aansluiting tussen het onderwijs en de arbeidsmarkt.

\section{Krapte op de arbeidsmarkt ook voor MBO'ers duidelijk waarneembaar}

In de afgelopen vijf jaar heeft de gunstige economische ontwikkeling geleid tot een groot tekort aan personeel. Ook MBO'ers zijn de afgelopen jaren zeer gewild. De krapte weerspiegelt zich in de lage werkloosheid. Minder dan $2 \%$ van de MBOschoolverlaters is zo'n anderhalf jaar na afstuderen werkloos. Het tekort aan personeel is ook op allerlei andere terreinen merkbaar. Zo zijn de lonen sterk gestegen. Schoolverlaters verdienen in 2001 zo'n 30\% meer dan schoolverlaters in 1997. In 2001 is de stijging het grootst: ongeveer 10\%. Deze sterkere loonstijging in 2001 houdt verband met zowel de krapte op de arbeidsmarkt als de sterk oplopende inflatie. De flexibilisering van de arbeidsmarkt was een aantal jaren geleden een hot item. Het tekort aan personeel heeft deze discussie wat naar de achtergrond gedrongen. In 1997 had 23\% van de MBO'ers een flexibele aanstelling. In 2001 is dit percentage meer dan gehalveerd: 11\%. De arbeidsmarkt oefent, onder meer als gevolg van de krapte, een steeds grotere aantrekkingskracht uit. In 1997 koos nog meer dan 30\% van de MBO-schoolverlaters voor een vervolgopleiding; in 2001 is dit minder dan een kwart.

\section{Werkgever waardeert werkervaring BBL'ers}

Hoewel de beroepsopleidende (BOL) en de beroepsbegeleidende leerweg ( $B B L)$ beogen de schoolverlaters een gelijkwaardige positie te verschaffen, blijken er in de transitie van school naar werk opmerkelijke verschillen waarneembaar. $\mathrm{Na}$ de opleiding vindt de BBL'er sneller werk, krijgt sneller een vaste aanstelling en verdient meer dan de BOL'er. De werkervaring die de BBL'er tijdens de opleiding heeft opgedaan wordt door de werkgever blijkbaar beloond. Ook de concrete ervaring die de werkgever heeft opgedaan met de BBL'er speelt mogelijk een rol. Overigens laat onderzoek zien dat de regulier opgeleiden de achterstand op de duaal opgeleiden snel inhalen.

BOL'ers kiezen vaker voor een vervolgopleiding dan BBL'ers. Over het algemeen kiest 35 tot $40 \%$ van de BOL'ers voor een vervolgopleiding. Maar liefst $85 \%$ tot $90 \%$ 
van de BBL'ers kiest voor de arbeidsmarkt. Dit wijst erop dat BBL'ers over het algemeen praktischer ingesteld zijn en meer gericht zijn op werk. De praktische en beroepsgerichte oriëntatie komt ook tot uiting in de studiekeuze. Doorstuderende BBL'ers lijken wat vaker voor een verwante opleiding te kiezen dan BOL'ers. De nadruk op beroepsgerichte vaardigheden maakt de overstap naar een niet-verwante opleiding voor de BBL'er wellicht wat moeilijker.

\section{Arbeidsmarktpositie van opleidingen niveau 3 en 4 beter dan van niveau 1 en 2}

De arbeidsmarkt voor opleidingen op niveau 3 en 4 ziet er rooskleurig uit. De werkloosheid is zeer laag. Met name de technische opleidingen en de opleidingen in de gezondheidszorg springen in het oog. De beloning is relatief hoog, het aantal flexibele contracten is laag en velen hebben een baan gevonden die goed aansluit bij de opleiding. De economische opleidingen blijven hierbij een beetje achter. Zo verdienen BBL'ers niveau 3 en 4 met een economische opleiding zo'n $€ 3$,- bruto per uur minder dan hun jaargenoten met een zorgopleiding. Hierbij dient wel opgemerkt te worden dat de kwaliteit van de aansluiting er voor economisch opgeleiden veel minder toe blijkt te doen dan voor opgeleiden in de gezondheidszorg. Wanneer er sprake is van een minder goede match tussen opleidings- en baanniveau heeft dat voor economisch opgeleiden veel minder gevolgen voor de beloning dan voor zorgopgeleiden. Dit maakt zorgopgeleiden die buiten hun 'eigen' domein werkzaam zijn toch enigszins kwetsbaar.

De arbeidsmarktpositie van opleidingen op niveau 1 en 2 is zwakker dan voor opleidingen op niveau 3 en 4 . Dit komt niet zozeer tot uiting in de werkloosheid. Door de krapte op de arbeidsmarkt, vinden ook de schoolverlaters met een diploma op niveau 1 en 2 vrijwel allemaal werk. De werkloosheid is dan ook onder deze lager opgeleiden laag (minder dan 4\%). MBO'ers met een diploma op niveau 1 en 2 hebben daarentegen vaker een flexibele aanstelling en werken vaker beneden hun niveau en buiten hun eigen richting dan schoolverlaters van opleidingen op niveau 3 en 4. Dit geldt vooral voor de BOL'ers met een economische of landbouwopleiding op niveau 1 en 2. Dit betekent veelal dat deze schoolverlaters terechtkomen op de zogenaamde 'secundaire arbeidsmarkt' in banen waarvoor nauwelijks of geen scholing vereist is.

\section{Meerderheid MBO'ers tevreden}

MBO'ers zijn over het algemeen tevreden met hun huidige situatie en kijken ook met voldoening terug op hun opleiding. Zo'n $20 \%$ van de MBO'ers die anderhalf jaar geleden zijn afgestudeerd is thans op zoek naar (ander) werk. Het aantal actieve zoekers is bij de schoolverlaters van economische opleidingen op niveau 1 en 2 het grootst (ongeveer 28\%).

Ruim driekwart van de MBO-schoolverlaters zou opnieuw voor dezelfde opleiding kiezen. De schoolverlaters van opleidingen op niveau 3 en 4 zijn het meest tevreden. Over het algemeen is ongeveer $80 \%$ achteraf tevreden met de keuze voor de afgesloten opleiding. Opvallend is dat dit percentage voor de economische oplei- 
dingen wat lager is; voor de BOL-opleidingen zelfs lager dan 70\%. BOL'ers niveau 1 en 2 zijn het minst tevreden. Ruim 60\% van de BOL'ers landbouw, techniek en economie op deze niveaus zou voor dezelfde opleiding kiezen. Van de spijtoptanten geeft ongeveer de helft aan liever een andere opleiding op hetzelfde niveau gevolgd te hebben.

\section{Over het algemeen redelijke tot goede perspectieven op de middellange termijn}

Het arbeidsmarktperspectief voor MBO'ers kan op de middellange termijn over het algemeen als redelijk tot (zeer) goed bestempeld worden. MBO-schoolverlaters zullen dan naar verwachting betrekkelijk gemakkelijk een baan vinden op een functieniveau en in een -richting waarop men toen men aan de opleiding begon zou mogen rekenen. Het specialistische karakter en de hoge conjunctuurgevoeligheid maakt met name technische opleidingen zoals installatietechniek en procestechniek echter kwetsbaar op de arbeidsmarkt. Deze technische opleidingen zijn erg afhankelijk van conjunctuurgevoelige bedrijfssectoren zoals de bouw en de chemie.

Ook zorgopleidingen, zoals verpleging en dokters-, tandarts en dierenartsassistent staan op termijn bloot aan een zeker risico. Weliswaar is het perspectief goed en zal een conjuncturele neergang niet meteen tot een sterke afname van de vraag naar schoolverlaters leiden, het smalle beroependomein en de afhankelijkheid van de zorg maakt schoolverlaters van deze opleidingen toch enigszins kwetsbaar.

Met name economische opleidingen worden gekenmerkt door een structureel sterke positie. Er zal naar verwachting de komende jaren niet alleen genoeg vraag naar schoolverlaters van deze opleidingen zijn. Een conjuncturele neergang zal bovendien een relatief gering effect hebben op deze vraag. Daarnaast zijn de verworven kwalificaties inzetbaar in een breed scala aan beroepen op MBO-niveau.

Slechts een beperkt aantal MBO-opleidingen heeft een matig of slecht arbeidsmarktperspectief. Schoolverlaters van deze opleidingen zullen naar verwachting over het algemeen veel moeite hebben om een passende baan te vinden. Zij zullen worden gedwongen een baan in een andere richting of onder hun niveau te accepteren, tegen minder gunstige arbeidsvoorwaarden te werken, meer en langer tijdelijk werk te accepteren of zullen zelfs werkloos worden. De opleidingen milieu en groene ruimte en uiterlijke verzorging hebben een relatief specialistische karakter. Niet alleen schiet de vraag naar verwachting de komende jaren tekort, schoolverlaters hebben bovendien weinig uitwijkmogelijkheden naar andere functies op MBO-niveau. Voor de opleidingen grafische techniek, brood en banket, levensmiddelentechniek/ vleesverwerking, sociaal-cultureel en beweging en therapie zijn de uitwijkmogelijkheden groter. Weliswaar zullen schoolverlaters van deze opleidingen moeite hebben een passende baan te vinden, de door hen verworven kwalificaties zijn wel breder inzetbaar op de arbeidsmarkt. Dit biedt hen de mogelijkheid ook buiten het eigen domein een functie te verwerven. 



\section{Inleiding}

Het middelbaar beroepsonderwijs speelt een belangrijke rol in het Nederlandse onderwijssysteem. Ongeveer de helft van de Nederlandse beroepsbevolking is middelbaar opgeleid. Het aandeel MBO'ers onder de huidige schoolverlaters is zelfs nog groter. Bovendien, en zeker niet in de laatste plaats, vervult het MBO een belangrijke rol in de voorbereiding op het hoger beroepsonderwijs. Een aanzienlijk deel van de HBO'ers zijn doorstromers vanuit het MBO.

Onderzoek laat zien dat het middelbaar beroepsonderwijs een sleutelrol vervult in de economische ontwikkeling ${ }^{1}$. Internationaal vergelijkend onderzoek laat bijvoorbeeld zien dat in landen waar het middelbaar beroepsonderwijs een kleine rol speelt, middelbaar opgeleiden een relatief laag aandeel hebben in bedrijven. Een voorbeeld vormt Groot-Brittannië. Onderzoek op bedrijfsniveau heeft laten zien dat een geringe vertegenwoordiging van middelbaar opgeleiden een negatieve invloed heeft op de productiviteit in deze bedrijven. Zo is er vaker sprake van vertraging in het productieproces. Ook de kwaliteit van de geleverde goederen en diensten blijkt lager. Dientengevolge blijken Britse ondernemingen hogere overheaduitgaven aan bijvoorbeeld kwaliteitscontrole en planning te maken dan bijvoorbeeld Franse en Duitse bedrijven. Middelbaar opgeleiden blijken bovendien een cruciale rol te spelen in de slagvaardigheid van een organisatie. Een groot aandeel middelbaar (en hoger) opgeleiden resulteert in platte organisatiestructuren, flexibele taakomschrijvingen en een grote nadruk op teamwork en kwaliteitszorg; factoren die een positief effect hebben op de slagvaardigheid van een organisatie.

In het licht van het belang van het middelbaar beroepsonderwijs, is een goede aansluiting tussen onderwijs en arbeidsmarkt en een goed verlopende transitie van school naar werk van groot belang. Deze rapportage zal de aansluiting tussen het onderwijs en de arbeidsmarkt voor MBO'ers vanuit een aantal gezichtspunten belichten. De nadruk ligt op het in kaart brengen van de transitie van school naar werk. Hiertoe zal een breed scala aan indicatoren voor de arbeidsmarktpositie van gediplomeerde MBO'ers de revue passeren. Daarnaast zal een blik in de toekomst worden geworpen. Hoe zal de arbeidsmarkt voor MBO'ers er over zo'n vijf jaar uitzien? En hoe kwetsbaar is de arbeidsmarktpositie van MBO'ers nu en in de toekomst?

Dit rapport richt zich in eerste instantie op degenen die zich in beleidsmatige zin bezighouden met de doorstroom van MBO'ers binnen het onderwijssysteem enerzijds en de arbeidsmarktpositie van gediplomeerde MBO'ers anderzijds. Daarbij wordt met name gedacht aan het (georganiseerde) onderwijsveld, landelijke en regionale overheden, CWl's en sociale partners.

1. Voor een overzicht, zie Heijke, H. (2001), 'Vocational Education from an Economic Point of View', in: Nieuwenhuis, L.F.M. \& W.J. Nijhof (eds), The Dynamics of VET and HRD Systems, Twente University Press, Enschede, pp. 169-180. 
Het rapport is als volgt opgebouwd. Hoofdstuk 2 laat zien wat MBO'ers na het afronden van hun opleiding zijn gaan doen. Hebben ze werk gevonden, hebben ze gekozen voor een vervolgopleiding of zijn ze iets anders gaan doen? Hoofdstuk 3 richt de schijnwerper op de werkende MBO'ers. Hoe zijn zij aan het werk gekomen? Onder welke arbeidsvoorwaarden zijn zij aan het werk? Hebben zij een vaste baan? Of heeft de flexibele arbeidsmarkt de laatste jaren aan belang gewonnen? Hoofdstuk 4 gaat dieper in op de aansluiting tussen opleiding en werk. Zit de MBO'er op zijn of haar plek? Of is er sprake van onderbenutting? Is men tevreden met het werk? Of is men op zoek naar een (andere) baan? En zou men, terugkijkend, opnieuw voor dezelfde opleiding hebben gekozen? Hoofdstuk 5 werpt een blik in de toekomst. Wat is het perspectief op de arbeidsmarkt voor MBO'ers tot 2006? Hoe gevoelig is dit perspectief voor de altijd onzekere en enigszins onvoorspelbare conjuncturele ontwikkeling? En hoe flexibel zijn MBO'ers op de arbeidsmarkt? Kunnen zij uitwijken naar andere arbeidsmarktsegmenten, wanneer het in het 'eigen' beroependomein even tegen zit?

Twee onderzoeken liggen aan de in dit rapport gepresenteerde cijfers ten grondslag. In de eerste plaats het schoolverlatersonderzoek RUBS (Registratie van Uitstroom en Bestemming van Schoolverlaters), gericht op schoolverlaters van het algemeen voortgezet onderwijs (MAVO, HAVO, VWO), het voorbereidend beroepsonderwijs (VBO) en de beroepsopleidende (BOL) en beroepsbegeleidende (BBL) leerwegen van het secundair beroepsonderwijs. RUBS maakt deel uit van een geïntegreerd monitoringinstrument van de transitie van school naar werk over de volle breedte van het onderwijs. De schoolverlaters worden ongeveer anderhalf jaar na het verlaten van de opleiding ondervraagd middels een schriftelijke vragenlijst. Deze vragenlijst bestaat ut een gedeelte dat voor elke onderwijssoort identiek is en uit een variabel gedeelte waarbij de inhoud afhankelijk is van de onderwijssoort en/of de opleidingssector. Bij BOL en BBL ligt de nadruk voornamelijk op de intrede op de arbeidsmarkt.

In de tweede plaats zijn de gegevens in dit rapport (hoofdstuk 5) gebaseerd op gegevens uit het Project Onderwijs-Arbeidsmarkt (POA). Middels dit project wordt getracht inzicht te verwerven in de huidige en toekomstige arbeidsmarktsituatie van de verschillende beroepen en opleidingen over de volle breedte van de arbeidsmarkt. Een centrale rol binnen POA spelen de verwachte ontwikkelingen op de middellange termijn. Er is voor een tijdshorizon van vijf jaar gekozen, om een zo goed mogelijk beeld te geven van arbeidsmarktsituatie bij afstuderen van degenen die thans aan het begin van de studie staan.

Dit rapport is samengesteld door drs. P. van Eijs. Verder is aan dit rapport meegewerkt door M. Beenkens, drs. T. Huijgen en E. Soudant. 


\section{Na de MBO-opleiding}

$\mathrm{Na}$ het afronden van de opleiding staat de MBO-schoolverlater een aantal mogelijkheden ter beschikking. Hij of zij kan kiezen voor de arbeidsmarkt en al dan niet succesvol op zoek gaan naar een baan. Ook een vervolgopleiding behoort tot de mogelijkheden. Dit kan een MBO-opleiding zijn op een hoger niveau of via een andere leerweg. De hoger opgeleide MBO'er kan kiezen voor een HBO-opleiding. In dit hoofdstuk staat de maatschappelijke positie van de MBO'ers zo'n anderhalf jaar na afstuderen centraal.

\section{MBO'ers kiezen minder vaak voor een vervolgopleiding}

Figuur 2.1 geeft een overzicht van de maatschappelijke positie van MBOschoolverlaters in de afgelopen vijf jaar. Uit de figuur blijkt dat MBO'ers de laatste jaren minder vaak kiezen voor een vervolgopleiding. In 1997 koos nog meer dan $30 \%$ voor een vervolgopleiding; in 2001 is dit minder dan een kwart. Onder meer als gevolg van het tekort aan personeel, oefent de arbeidsmarkt een steeds grotere aantrekkingskracht uit. Meer dan 70\% van de MBO'ers kiest in 2001 voor een betaalde baan. De krapte op de arbeidsmarkt weerspiegelt zich ook in de lage werkloosheid. Minder dan $2 \%$ van de schoolverlaters is zo'n anderhalf jaar na afstuderen werkloos. Dit percentage is de afgelopen vijf jaar min of meer stabiel.

Figuur 2.1

De arbeidsmarktpositie van MBO-schoolverlaters, 1997-2001

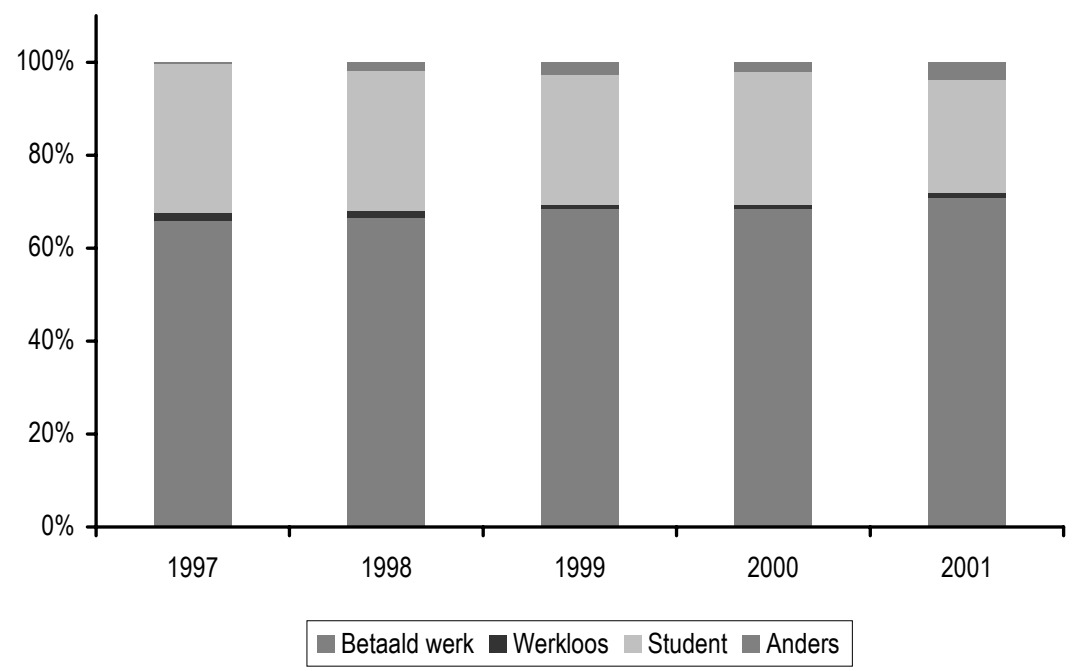

Bron: ROA (RUBS) 


\section{BBL'ers kiezen vaker voor de arbeidsmarkt dan BOL'ers}

Het in figuur 2.1 geschetste beeld verschilt echter sterk per opleidingssector. Figuur 2.2 laat zien dat in 2001 schoolverlaters van de beroepsopleidende leerweg (BOL) relatief vaak voor een vervolgopleiding kiezen ${ }^{2}$. Schoolverlaters van de beroepsbegeleidende leerweg (BBL) kiezen daarentegen vaak voor de arbeidsmarkt. Dit wijst erop dat BBL'ers over het algemeen praktischer ingesteld zijn en meer gericht zijn op werk. Over het algemeen kiest 35 tot $40 \%$ van de BOL'ers voor een vervolgopleiding. Voor schoolverlaters van landbouwopleidingen ligt dit percentage wat lager. Zorgopgeleiden met niveau 1 of 2 kiezen het vaakst voor een vervolgopleiding. Maar liefst $85 \%$ tot $90 \%$ van de BBL'ers kiest voor de arbeidsmarkt. Technisch en economisch opgeleide BBL'ers kiezen wat minder vaak voor betaald werk. Schoolverlaters met een diploma op niveau 1 en 2 zijn wat vaker werkloos, maar ook hier bedraagt de werkloosheid niet meer dan $4 \%$. Van alle opleidingen hebben economisch en technisch opgeleiden nog het meeste moeite een baan te vinden.

Figuur 2.2

De arbeidsmarktpositie van schoolverlaters naar opleidingssector, 2001

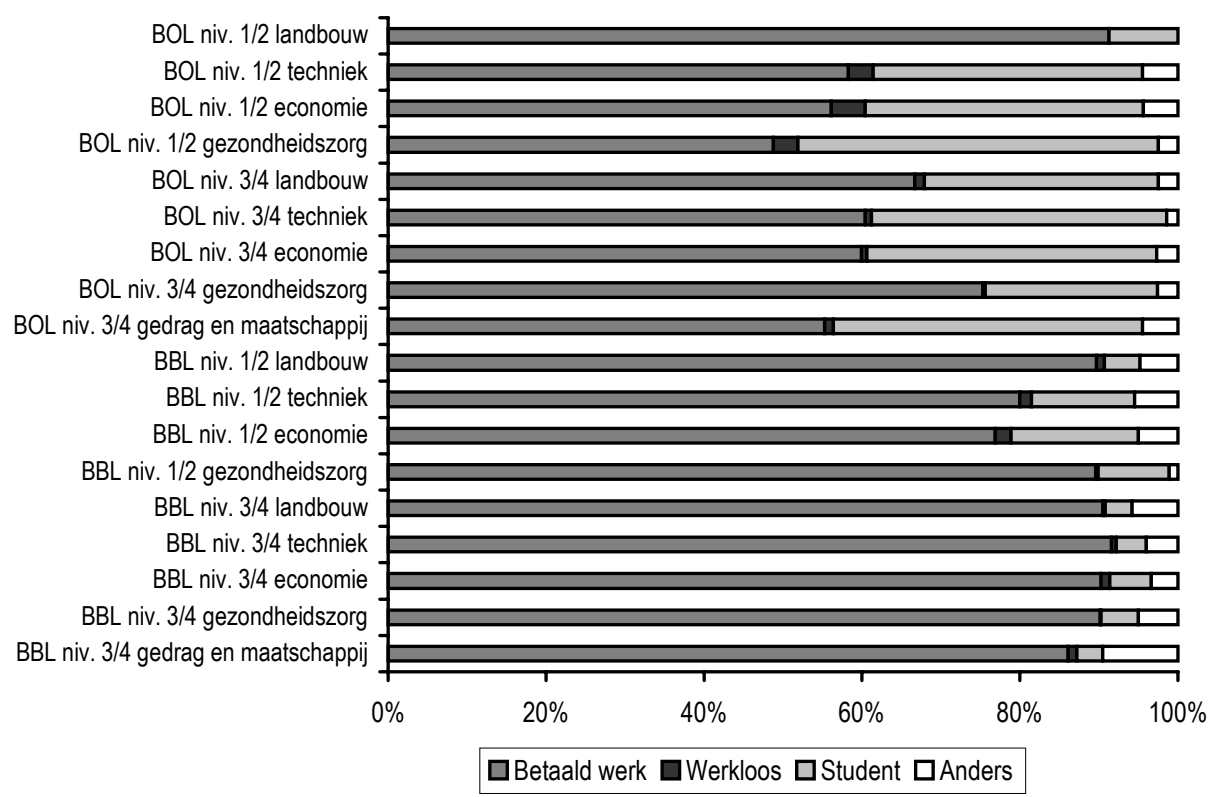

Bron: ROA (RUBS)

2. In de bijlage achter in dit rapport wordt een overzicht gegeven van de verschillende leerwegen en niveaus binnen het middelbaar beroepsonderwijs. We maken in dit rapport een onderscheid tussen de beroepsopleidende (BOL) en de beroepsbegeleidende leerweg (BBL). Het geheel wordt als MBO aangeduid. 
Tabel 2.1 biedt inzicht in de verschillen in de arbeidsmarktpositie naar geslacht en etniciteit. De tabel laat zien dat er in 2001 nauwelijks verschillen zijn tussen mannen en vrouwen. Allochtonen kiezen opvallend vaak voor een vervolgopleiding. Ruim $30 \%$ van de allochtonen kiest ervoor om verder te studeren. Onder de autochtone schoolverlaters is dit minder dan een kwart. De werkloosheid onder allochtonen is anderhalf jaar na afstuderen met $4 \%$ wat hoger dan onder autochtonen.

Tabel 2.1

De arbeidsmarktpositie van MBO-schoolverlaters naar geslacht en etniciteit, 2001, percentages

\begin{tabular}{lrrrrr}
\hline Positie & Man & Vrouw & Allochtoon & Autochtoon & Totaal \\
\hline Betaald werk & 71 & 71 & 61 & 72 & 71 \\
Werkloos & 1 & 2 & 4 & 1 & 1 \\
Student & 24 & 24 & 31 & 23 & 4 \\
Anders & 4 & 4 & 5 & 4 & 4 \\
\hline
\end{tabular}

Bron: ROA (RUBS)

Schoolverlaters niveau 3 en 4 hebben goede start

We hebben reeds gezien dat bijna alle MBO'ers, die na afstuderen hebben gekozen voor de arbeidsmarkt, anderhalf jaar na afstuderen een baan hebben gevonden. Alleen allochtonen en schoolverlaters van opleidingen op niveau 1 en 2 ondervinden, ondanks de arbeidsmarktkrapte wat meer moeite. Daarnaast is het zinvol te kijken naar de wijze waarop de starter zijn weg vindt op de arbeidsmarkt. Is er sprake van een moeizame start? Of is de overgang van school naar werk gladjes verlopen?

Figuur 2.3

Intredewerkloosheid onder MBO'ers van vier maanden of langer naar opleidingssector, 2001 BOL niv. 1/2 landbouw
BOL niv. $1 / 2$ techniek
BOL niv. $1 / 2$ economie BOL niv. $1 / 2$ gezondheidszorg

BOL niv. $3 / 4$ landbouw

BOL niv. $3 / 4$ techniek

BOL niv. $3 / 4$ economie BOL niv. $3 / 4$ gezondheidszorg BOL niv. $3 / 4$ gedrag en maatschappij BBL niv. 1/2 landbouw

BBL niv. 1/2 techniek BBL niv. 1/2 economie BBL niv. 1/2 gezondheidszorg

BBL niv. 3/4 landbouw

BBL niv. 3/4 techniek BBL niv. 3/4 economie BBL niv. 3/4 gezondheidszorg BBL niv. 3/4 gedrag en maatschappij

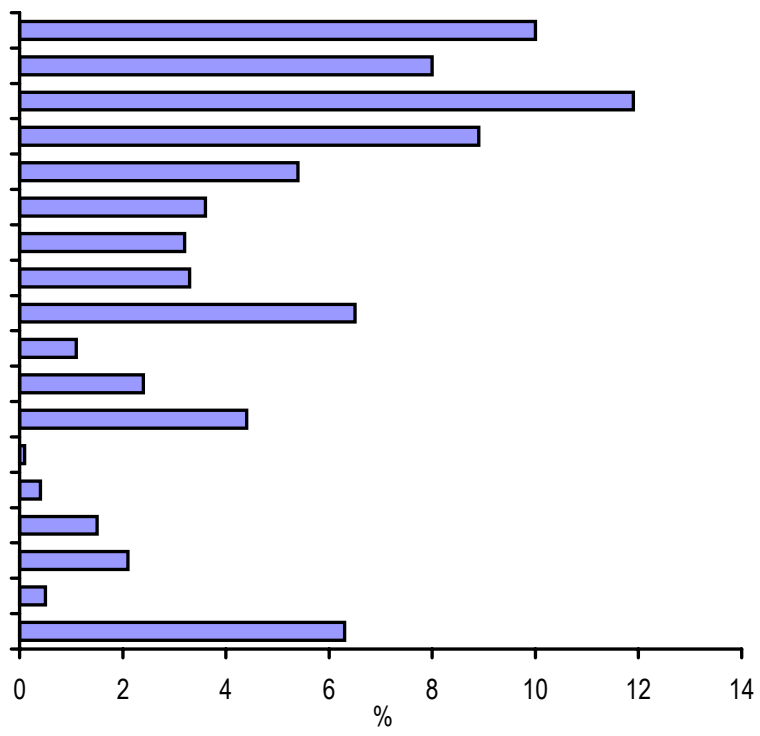

Bron: ROA (RUBS) 
Een indicator voor deze startersproblematiek is de intredewerkloosheid. MBO'ers vinden over het algemeen snel werk. Slechts $4 \%$ van de MBO-schoolverlaters heeft er langer dan drie maanden over gedaan om de eerste baan te vinden. Figuur 2.3 toont de verschillen naar opleidingssector. De lager opgeleiden met een BOL-diploma zijn relatief langer werkloos. In de sector BOL niveau 1 en 2 economie is de intredewerkloosheid het hoogst. Bijna $12 \%$ van de schoolverlaters doet er langer dan drie maanden over een baan te verwerven. BBL'ers ondervinden nauwelijks problemen. De werkervaring opgedaan tijdens de opleiding biedt de BBL'er de mogelijkheid snel een baan te verwerven of in de meeste gevallen te behouden. Onder schoolverlaters met een diploma op niveau 3 en 4 is de intredewerkloosheid over het algemeen laag. Vermeldenswaard is echter de hoge intredewerkloosheid in de sectoren BOL en BBL gedrag en maatschappij niveau 3 en 4 . We hebben eerder gezien dat na anderhalf jaar de werkloosheid in deze sectoren niet substantieel hoger is dan in andere sectoren.

Figuur 2.4

Percentage MBO-schoolverlaters dat werkloos is geweest naar opleidingssector, 2001

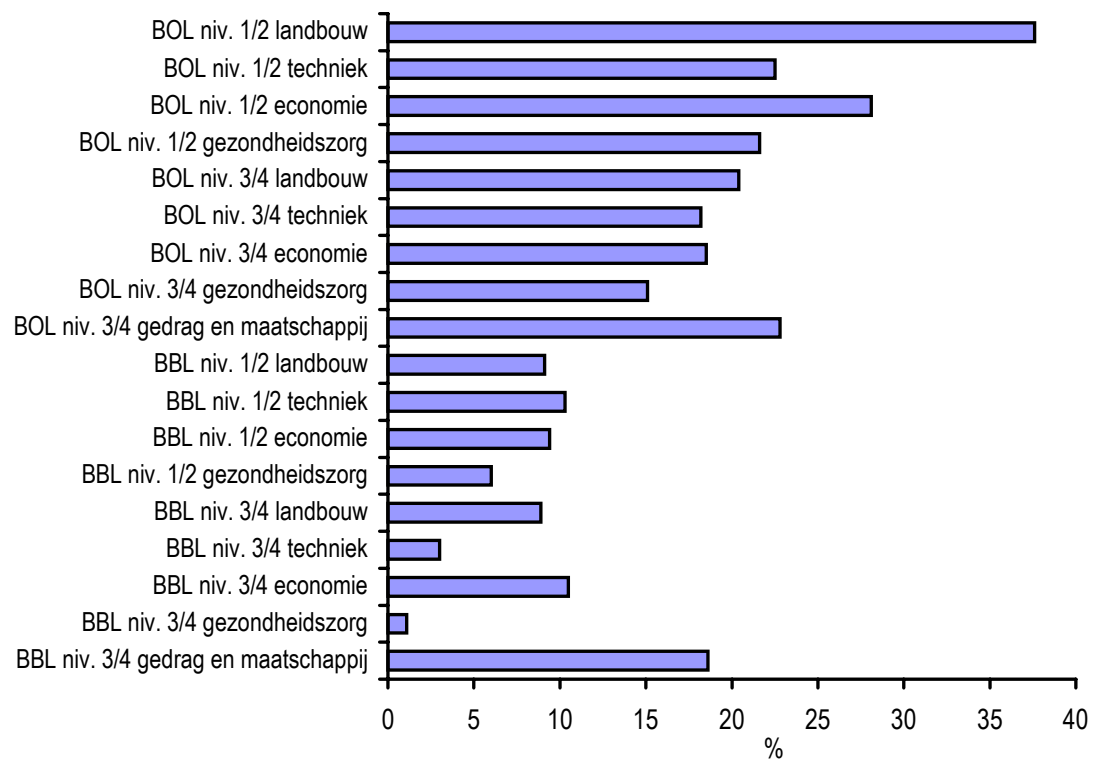

Bron: ROA (RUBS)

Een tweede indicator voor een eventuele startersproblematiek is het percentage schoolverlaters dat werkloos is geweest gedurende de eerste anderhalf jaar van de beroepsloopbaan. Figuur 2.4 geeft hiervan een overzicht. Met name de BOL'ers niveau 1 en 2 worden geconfronteerd met werkloosheid. Bijna 40\% van de schoolverlaters in de sector BOL niveau 1 en 2 landbouw is gedurende de eerste anderhalf jaar wel eens werkloos geweest. In de regel betreft dat de werkloosheid tussen het verlaten van de school en de eerste baan. De sector BOL niveau 1 en 2 economie scoort opnieuw hoog. Het verschil tussen BOL'ers en BBL'ers komt in deze figuur nog sterker tot uiting dan in figuur 2.3. Meer dan $15 \%$ van de BOL'ers - ook schoolverlaters van niveau 3 en 4 - wordt met werkloosheid geconfronteerd. Onder 
BBL'ers is dit over het algemeen $10 \%$ of minder. Opnieuw springen de gedrag en maatschappij-opleidingen in het oog. Ongeveer $20 \%$ van de schoolverlaters van deze opleidingen is werkloos geweest. Zeker binnen de beroepsbegeleidende leerweg is dit een opvallend hoog percentage.

\section{Doorstroom naar verwante opleiding niet vanzelfsprekend}

We richten ons vizier nu op de verder lerende schoolverlaters. Het Nederlandse onderwijssysteem biedt de student een grote variëteit aan leerroutes. Vanuit het onderwijs is het interessant om na te gaan in hoeverre MBO-schoolverlaters kiezen voor een verwante opleiding. Kiest men voor een opleiding binnen de beroepskolom of waaiert men uit naar een breed scala aan opleidingen? Figuur 2.5 laat een gevarieerd beeld zien. Binnen de sector BBL niveau 3 en 4 landbouw stroomt minder dan de helft van de schoolverlaters die kiezen voor een vervolgopleiding door naar een verwante opleiding. Binnen de sectoren BOL en BBL niveau 1 en 2 techniek is dit meer dan $90 \%$. BBL'ers lijken wat vaker voor een verwante opleiding te kiezen dan BOL'ers. Dit zou verband kunnen houden met de wat meer praktische en beroepsgerichte oriëntatie van BBL-opleidingen. Mogelijk speelt ook de relatie met het leerbedrijf een rol. BBL'ers blijven wellicht bij het leerbedrijf en kiezen een opleiding in overleg met dit leerbedrijf. De nadruk op beroepsgerichte vaardigheden maakt de overstap naar een niet-verwante opleiding wat moeilijker. Schoolverlaters van technische en economische opleidingen lijken relatief vaak door te stromen naar een verwante opleiding. We zagen al eerder dat technisch en economisch opgeleiden over het algemeen vaak voor een vervolgopleiding kiezen.

Figuur 2.5

Doorstroom van verder lerende MBO'ers naar verwante opleidingen naar opleidingssector, 2001

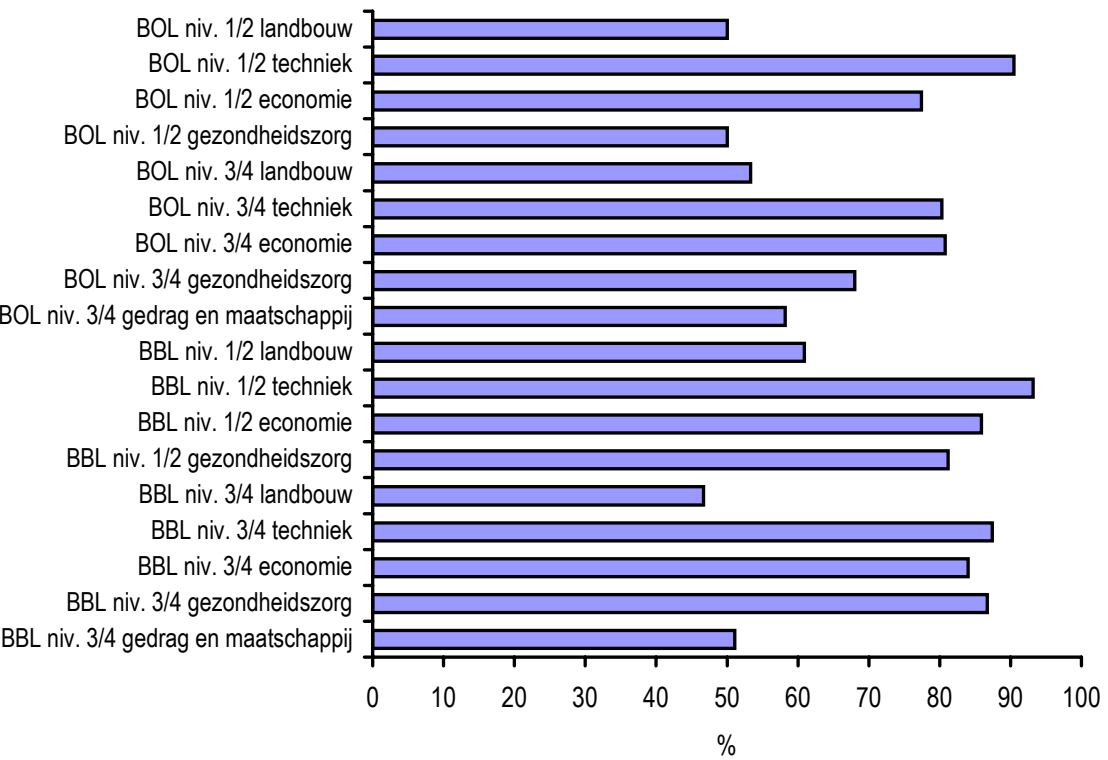

Bron: ROA (RUBS) 



\section{MBO'ers aan het werk}

In dit hoofdstuk bekijken we de positie van de werkende MBO'er. In het vorige hoofdstuk hebben we gezien dat ongeveer $70 \%$ van de schoolverlaters zo'n anderhalf jaar na afstuderen betaald werk heeft. De vraag rijst hoe zij aan werk zijn gekomen. Daarnaast is het interessant om in te gaan op de vraag hoe goed de MBO'er rendeert op de arbeidsmarkt. We bekijken daartoe twee aspecten: de werkzekerheid en de beloning. Beide aspecten vormen bovendien belangrijke indicatoren voor de arbeidsmarktpositie van MBO'ers.

BOL'ers vinden op vele manieren werk

Tabel 5.1 geeft een overzicht van de wijze waarop BOL'ers hun huidige baan hebben verworven. De stage blijkt een belangrijk middel om werkgevers en schoolverlaters tot elkaar te brengen. Blijkbaar gebruiken werkgevers de stageplaatsen als wervingsbron voor nieuw personeel. Ook de open sollicitatie wordt veel gebruikt. De traditionele advertentie blijkt van ondergeschikt belang op de arbeidsmarkt voor BOL'ers. De verschillen tussen niveau 1 en 2 enerzijds en niveau 3 en 4 anderzijds zijn gering. De stage speelt op de arbeidsmarkt voor schoolverlaters van niveau 3 en 4 een wat grotere rol.

Tabel 3.1

Wervingskanalen BOL'ers, 2001, percentages*

\begin{tabular}{lcc}
\hline Zoekkanaal & BOL niveau 1 en 2 & BOL niveau 3 en 4 \\
\hline Uitzendbureau, commercieel bemiddelingsbureau & 13 & 12 \\
Gereageerd op advertentie & 13 & 18 \\
Via open sollicitatie & 17 & 18 \\
Via stage & 18 & 25 \\
Via familie, vrienden of kennissen & 15 & 11 \\
Anders & 24 & 17
\end{tabular}

* Deze vraag is niet landelijk voorgelegd aan BBL'ers.

Bron: ROA (RUBS)

\section{Flexibele arbeidsmarkt gehalveerd}

De flexibilisering van de arbeidsmarkt was een aantal jaren geleden een hot item. Flexibilisering werd gezien als een belangrijk middel om de slagvaardigheid van bedrijven te bevorderen en de kansen van werknemers op de arbeidsmarkt te vergroten. Het tekort aan personeel van de laatste jaren heeft deze discussie wat naar de achtergrond gedrongen. Figuur 3.1 illustreert dit. De figuur laat zien hoeveel MBO-schoolverlaters anderhalf jaar na afstuderen werkzaam zijn met een flexibel arbeidscontract. Dit zijn banen via een uitzendbureau, als oproepkracht, of met een tijdelijke aanstelling zonder uitzicht op een vaste baan of met een aanstelling met een duur korter dan een jaar. De figuur laat zien dat het aandeel van flexibele arbeidskrachten de laatste vijf jaar is gehalveerd. In 1997 had 23\% van de MBO'ers een flexibele aanstelling. In 2001 is dit nog maar $11 \%$. 
Figuur 3.1

MBO-schoolverlaters met een flexibel arbeidscontract, 1997-2001

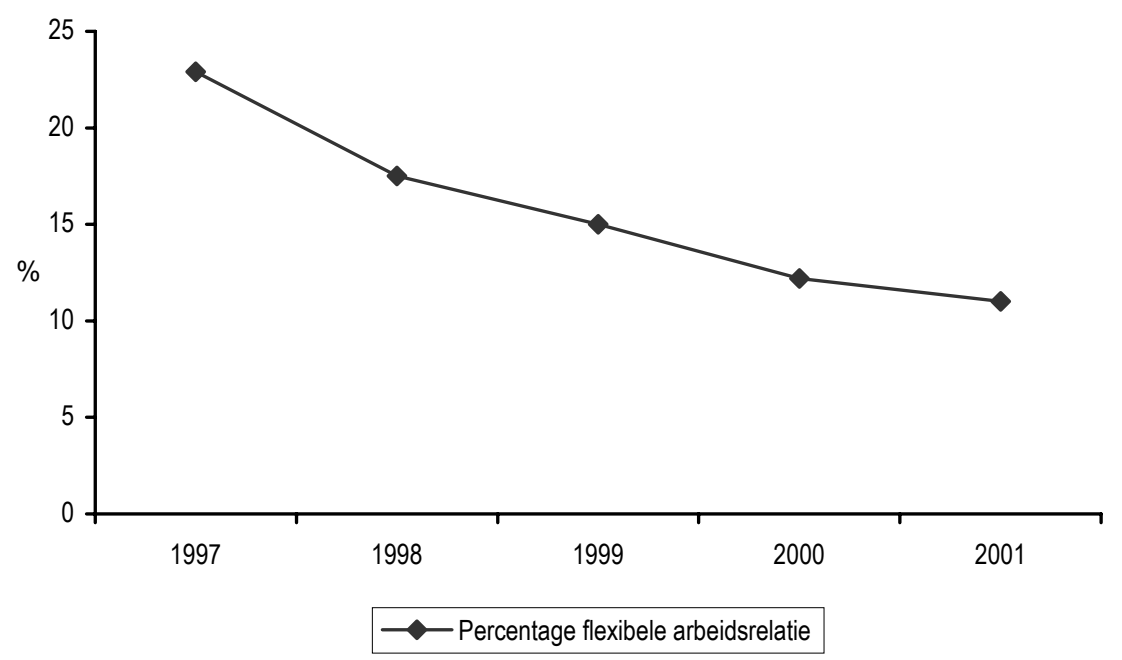

Bron: ROA (RUBS)

BOL'ers hebben vaker een flexibel arbeidscontract

Hoewel de flexibele arbeidsmarkt sterk aan belang heeft ingeboet, spelen flexibele arbeidscontracten op bepaalde delen van de arbeidsmarkt nog altijd een belangrijke rol. Figuur 3.2 laat de verschillen tussen de opleidingssectoren binnen het MBO zien. Het meest in het oog springt het verschil tussen BOL en BBL. BOL'ers werken veel vaker met een flexibel arbeidscontract dan BBL'ers. Blijkbaar kijken werkgevers bij BOL'ers wat vaker de kat uit de boom. De werkervaring die BBL'ers tijdens hun opleiding hebben opgedaan, wordt door de werkgever beloond met een grotere werkzekerheid. Werkgevers zullen zelfs al vaak concrete ervaring met de betrokkenen hebben opgedaan tijdens de opleiding. Verder lijken schoolverlaters met een diploma op niveau 1 of 2 vaker een flexibel contract te hebben dan schoolverlaters met een diploma op niveau 3 of 4 . Ook bij de lager opgeleiden zijn de werkgevers dus wat voorzichtiger. Het percentage flexibele contracten is het hoogst voor de sector BOL niveau 1 en 2 landbouw: ruim 34\%. Ook BOL niveau 1 en 2 economie scoort hoog: bijna $24 \%$. De laagste percentages zijn terug te vinden bij de BBLopleidingen op niveau 3 en 4 . Maar ook voor de sector BOL niveau 3 en 4 gezondheidszorg is het percentage flexibele arbeidscontracten opvallend laag. 
Figuur 3.2

MBO-schoolverlaters met een flexibele arbeidscontract naar opleidingssector, 2001

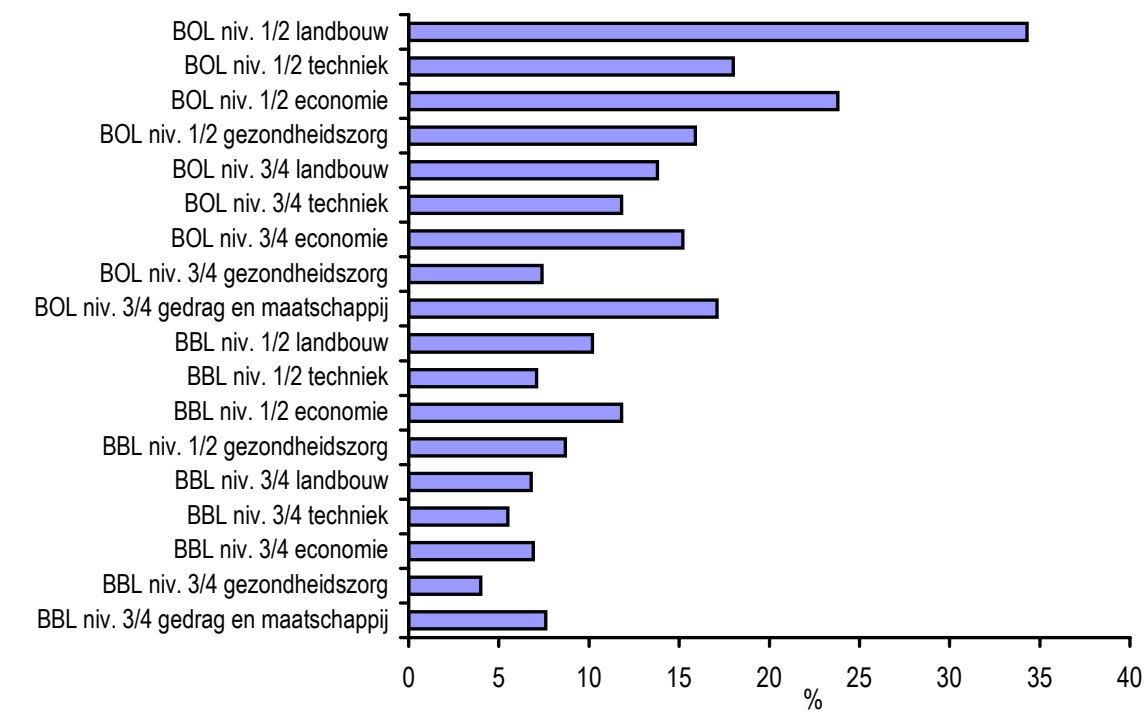

Bron: ROA (RUBS)

Lonen vooral in 2001 sterk gestegen

Een belangrijke indicator voor de arbeidsmarktpositie van opleidingen vormt de beloning. De beloning geeft immers een directe indicatie van de waarde van de verworven kwalificaties op de arbeidsmarkt. Figuur 3.3 laat de loonontwikkeling gedurende de afgelopen vijf jaar zien. De lonen zijn de afgelopen jaren sterk gestegen. Schoolverlaters verdienen in 2001 zo'n 30\% meer dan schoolverlaters in 1997. In 2001 was de stijging het grootst: ongeveer 10\%. Deze sterkere loonstijging in 2001 houdt zowel verband met de krapte op de arbeidsmarkt als met de sterk oplopende inflatie. Opvallend is het verschil in beloning tussen BOL'ers en BBL'ers. BBL'ers verdienen aanzienlijk meer dan BOL'ers. We hebben al eerder gezien dat de werkgever de werkervaring die BBL'ers tijdens hun opleiding hebben opgedaan belonen met een grotere werkzekerheid. Deze waardering komt dus ook in de beloning tot uiting. Als gevolg hiervan is de beloning voor schoolverlaters van BBLopleidingen niveau 3 en 4 het hoogst. BOL'ers niveau 1 en 2 verdienen verreweg het minst. Overigens laat onderzoek zien dat de regulier opgeleiden de achterstand in de beloning op de duaal opgeleiden snel inhalen ${ }^{3}$.

3. Velden, R. van der \& Lodder, B. (1995), Alternative routes from vocational education to the labor market, Educational Research and Evaluation, 1, pp. 109-128. 
Figuur 3.3

Ontwikkeling mediaan bruto uurloon MBO-schoolverlaters (exclusief nevenfuncties) naar leerweg en niveau in euro's, 1997-2001

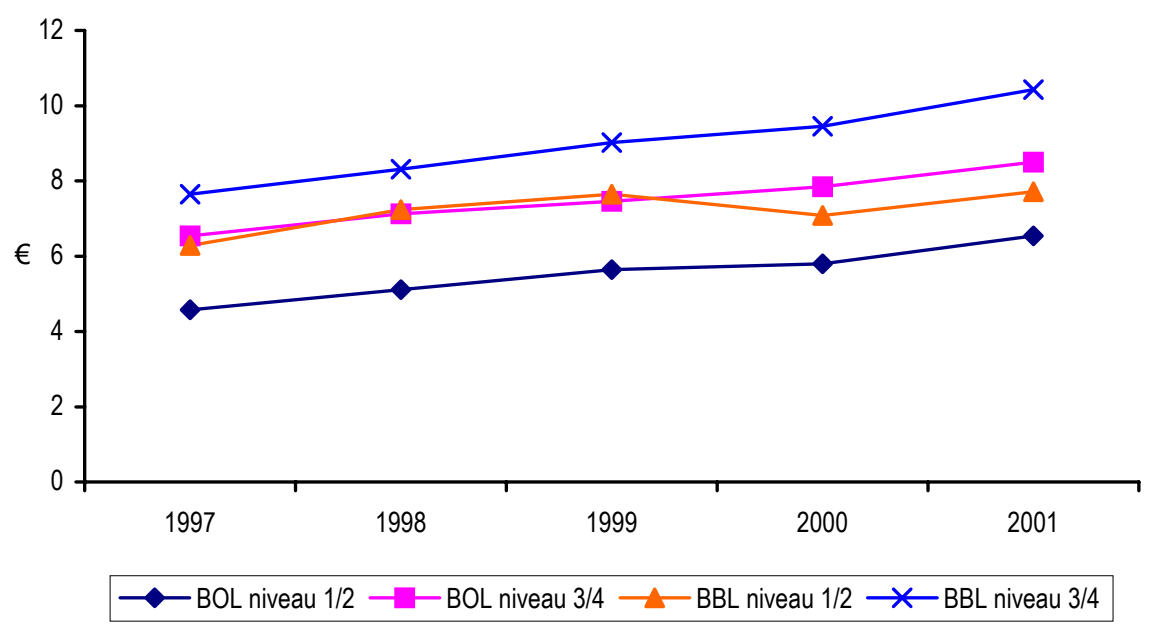

Bron ROA (RUBS)

Figuur 3.4

Mediaan bruto uurloon MBO-schoolverlaters (exclusief nevenfuncties) naar opleidingssector in euro's, 1997-2001

BOL niv. 1/2 landbouw

BOL niv. $1 / 2$ techniek

BOL niv. $1 / 2$ economie

BOL niv. 1/2 gezondheidszorg

BOL niv. $3 / 4$ landbouw

BOL niv. $3 / 4$ techniek

BOL niv. 3/4 economie

BOL niv. $3 / 4$ gezondheidszorg BOL niv. 3/4 gedrag en maatschappij

BBL niv. 1/2 landbouw

BBL niv. 1/2 techniek

BBL niv. 1/2 economie

BBL niv. 1/2 gezondheidszorg

BBL niv. 3/4 landbouw

BBL niv. 3/4 techniek

BBL niv. $3 / 4$ economie

BBL niv. 3/4 gezondheidszorg BBL niv. 3/4 gedrag en maatschappij
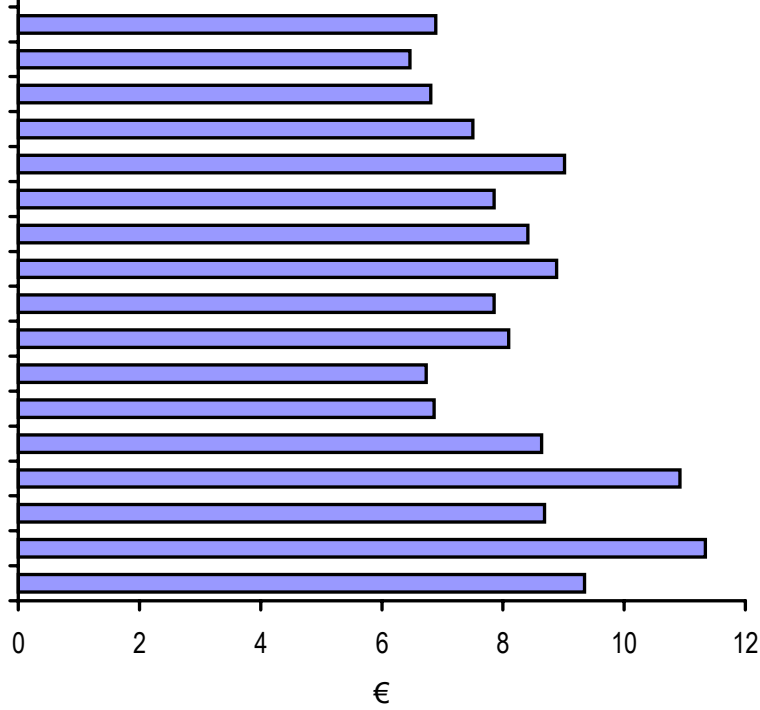

Bron: ROA (RUBS) 
Technische opleidingen en opleidingen in de gezondheidszorg het best beloond

Figuur 3.3 liet zien dat BBL'ers zo'n anderhalf jaar na afstuderen beter beloond worden dan BOL'ers. Echter, niet alleen de leerweg doet ertoe, de beloning verschilt ook per sector. Figuur 3.4 illustreert dit. Ongeacht de leerweg en het niveau worden technisch opgeleiden beter beloond dan hun collega's. Ook de gezondheidszorg springt erg in het oog. Zo verdienen schoolverlaters uit de opleidingssector BBL niveau 3 en 4 gezondheidszorg met een bruto uurloon van ruim $€ 11$ het meest. De beloning van BBL'ers niveau 3 en 4 economie blijft hier bijvoorbeeld bijna $€ 3$ bij achter. De beloning van degenen met een landbouwopleiding blijft in de regel sterk achter. 



\section{Zit de MBO'er op zijn plek?}

Dit hoofdstuk gaat dieper in op de aansluiting tussen opleiding en werk. De aansluiting wordt vanuit twee invalshoeken bekeken. In de eerste plaats komt de inhoudelijke aansluiting aan de orde, dat wil zeggen: in hoeverre sluiten de in de opleiding verworven kwalificaties aan op de functievereisten. Vervolgens kijken we naar de gevolgen van een gebrekkige aansluiting voor de beloning (als indicator voor het functioneren in de baan). In de tweede plaats belichten we de manier waarop de MBO'er zelf tegen zijn of haar huidige positie aankijkt. Twee indicatoren worden voor het voetlicht gebracht: de tevredenheid met de huidige situatie en de tevredenheid achteraf met de opleidingskeuze.

\section{Onderbenutting min of meer stabiel}

Een belangrijke indicator voor de aansluiting tussen onderwijs en arbeidsmarkt is de mate van onderbenutting. $\mathrm{Er}$ is sprake van onderbenutting wanneer het door de werkgever vereiste opleidingsniveau lager is dan het verworven opleidingsniveau. Figuur 4.1 toont het percentage onderbenutting bij MBO-schoolverlaters gedurende de afgelopen vijf jaar. De figuur laat zien dat het percentage MBO-schoolverlaters dat zo'n anderhalf jaar na afstuderen beneden zijn of haar niveau werkt min of meer stabiel is.

Figuur 4.1

Onderbenutting bij MBO-schoolverlaters, 1997-2001

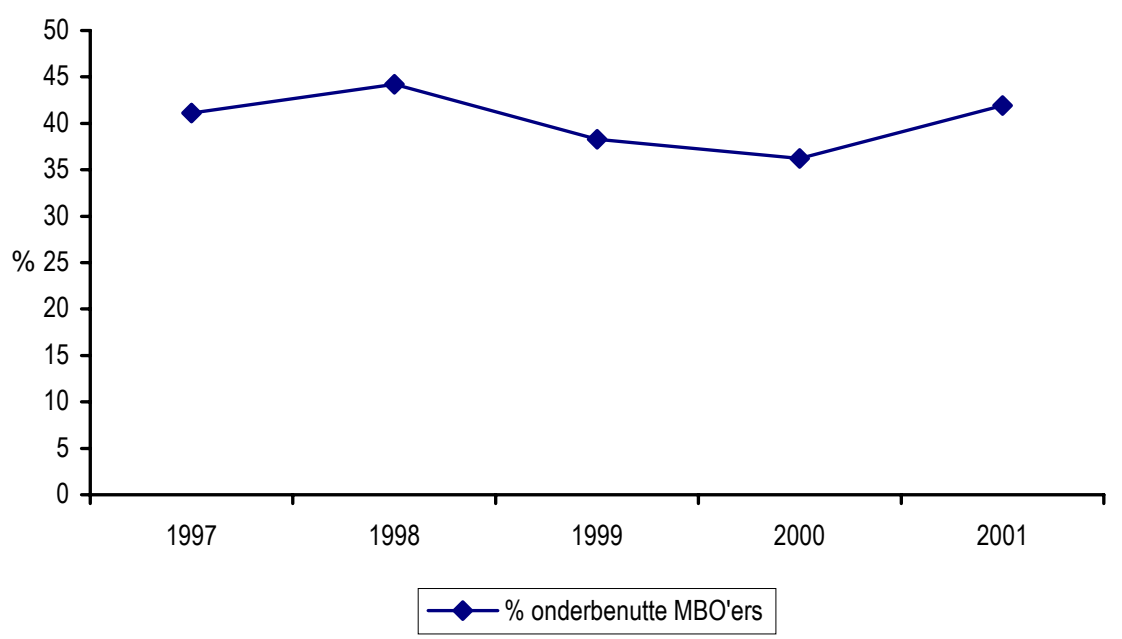

Bron: ROA (RUBS)

Schoolverlaters niveau 1 en 2 ondervinden grotere aansluitingsproblemen

Figuur 4.2 toont de kwalitatieve aansluitingsproblematiek tussen opleiding en beroepspraktijk naar opleidingssector. We onderscheiden twee dimensies. De eerste dimensie is de mate van onderbenutting. Ook het al dan niet kunnen toepassen van de in de opleiding verworven kwalificaties is een belangrijke maatstaf voor de 
kwaliteit van het werk en van de arbeidsmarktpositie. De tweede dimensie van de aansluitingsproblematiek tussen opleiding en beroepspraktijk wordt daarom gevormd door de vraag in hoeverre de baan aansluit bij de opleidingsrichting. Ruim $40 \%$ van de MBO-schoolverlaters geeft in 2001 aan beneden zijn of haar niveau werkzaam te zijn, terwijl ruim $30 \%$ aangeeft een baan te hebben waarin geen of een geheel andere opleidingsrichting door de werkgever wordt vereist. Deze twee gemiddelden delen de figuur in vier vlakken. Linksonder bevinden zich de schoolverlaters met een kwalitatief goede aansluiting. Schoolverlaters van deze opleidingssectoren hebben relatief vaak werk gevonden dat goed aansluit bij de opleiding. Het betreft hier met name opleidingen op niveau 3 en 4 , zoals BOL niveau 3 en 4 techniek, BOL en BBL niveau 3 en 4 gedrag en maatschappij en BOL en BBL niveau 3 en 4 gezondheidszorg. Opleidingen binnen deze sectoren hebben vaak een sterk vakspecifiek karakter.

Figuur 4.2

De kwalitatieve aansluiting tussen MBO-opleiding en beroepspraktijk naar opleidingssector, 2001

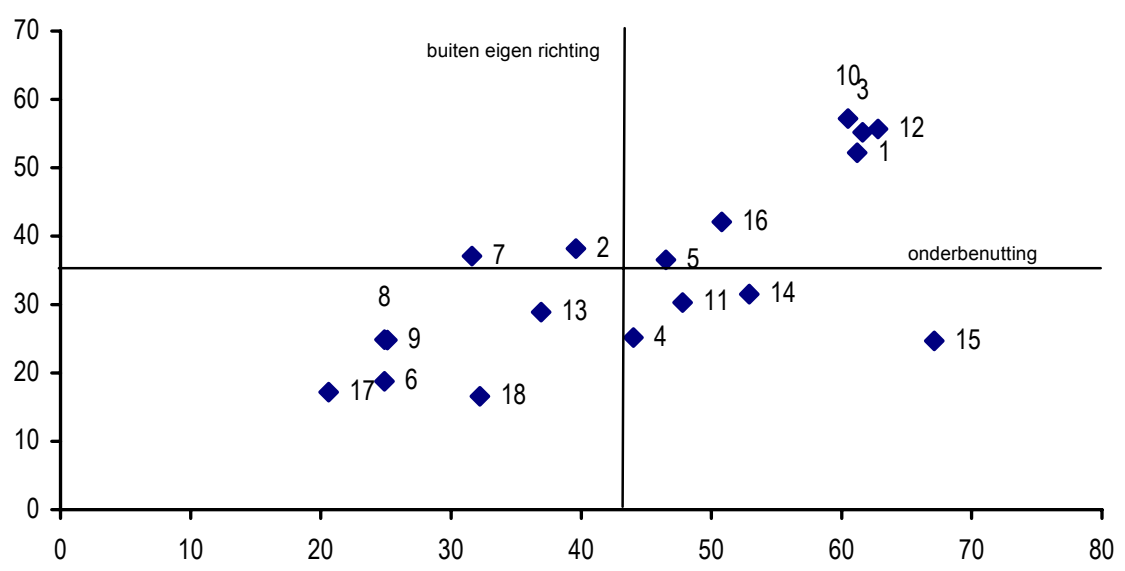

$1=\mathrm{BOL}$ niv. $1 / 2$ landbouw; $2=\mathrm{BOL}$ niv. $1 / 2$ techniek; $3=\mathrm{BOL}$ niv. $1 / 2$ economie; $4=\mathrm{BOL}$ niv. $1 / 2$ gezondheidszorg; $5=$ BOL niv. $3 / 4$ landbouw; $6=$ BOL niv. $3 / 4$ techniek; $7=\mathrm{BOL}$ niv. $3 / 4$ economie; $8=$ BOL niv. $3 / 4$ gezondheidszorg; $9=$ BOL niv. $3 / 4$ gedrag en maatschappij; $10=$ BBL niv. $1 / 2$ landbouw; $11=$ BBL niv. $1 / 2$ techniek; $12=$ BBL niv. $1 / 2$ economie; $13=\mathrm{BBL}$ niv. $1 / 2$ gezondheidszorg; $14=$ BBL niv. $3 / 4$ landbouw; $15=$ BBL niv. $3 / 4$ techniek; $16=$ BBL niv. $3 / 4$ economie; $17=$ BBL niv. 3/4 gezondheidszorg; $18=$ BBL niv. 3/4 gedrag en maatschappij Bron: ROA (RUBS)

Tegenover de opleidingen met een sterk vakspecifiek karakter staan de opleidingssectoren met zowel een hoog percentage onderbenutting als een hoog percentage schoolverlaters dat werkzaam is buiten de eigen vakrichting. Schoolverlaters van deze opleidingssectoren, rechtsboven in de figuur, moeten noodgedwongen vaak werk accepteren beneden hun niveau en buiten hun vakrichting. Het betreft hier vooral agrarische en economische opleidingssectoren. Bij de opleidingen op niveau 1 en 2 betekent dit veelal dat de schoolverlaters terecht komen op de zogenaamde 'secundaire arbeidsmarkt' in banen waarvoor nauwelijks of geen scholing vereist is. Bij de opleidingen op niveau 3 en 4 kan het juist betekenen dat de zij breed inzetbaar zijn en vanuit een wat mindere startpositie mogelijk toch een goed carrièreperspectief hebben. 
Rechtsonder bevinden zich de schoolverlaters die weliswaar beneden hun niveau, maar wel in hun eigen vakrichting werken. Het betreft hier vooral BBL-opleidingen. BBL'ers lijken grote moeite te hebben een baan op niveau te verwerven. Dit is een, ook uit eerder onderzoek, bekend resultaat. Vaak blijken BBL'ers het baanniveau echter te onderschatten en zijn zij toch op MBO-niveau werkzaam. Mogelijk zijn zij bij hun leerbedrijf gebleven en beoordelen zij de aansluiting op basis van de leerplaats. Er bevinden zich slechts twee opleidingssectoren in de linkerbovenhoek waar de onderbenutting relatief gering is, maar men wel wat meer dan gemiddeld buiten de vakrichting werkzaam is. Het gaat hierbij om de BOL opleidingssectoren niveau 3 en 4 economie en niveau 1 en 2 techniek.

\section{Een goede aansluiting loont}

De beloning geeft op twee manieren een indicatie van succes op de arbeidsmarkt. Het is een directe indicator. Hoe hoger de beloning, hoe succesvoller iemand is op de arbeidsmarkt. De beloning kan ook op indirecte wijze een indicator zijn voor de arbeidsmarktpositie. Hoe beter de aansluiting tussen opleiding en beroepspraktijk, met andere woorden: hoe beter de match, hoe beter iemand functioneert in de baan. Verwacht mag worden dat dit goede functioneren wordt beloond door de werkgever. Kortom: hoe beter de match, hoe hoger het loon. Tabel 4.1 laat zien in hoeverre de aansluiting tussen het niveau van de opleiding en het baanniveau invloed heeft op de beloning. Verwacht mag worden dat onderbenutting leidt tot een geringer beroep op de verworven kwalificaties, hetgeen zou kunnen resulteren in een lagere productiviteit en daarmee in een lagere beloning.

Tabel 4.1

De relatie tussen het gemiddeld bruto uurloon in euro's en onderbenutting naar opleidingssector, 2001

\begin{tabular}{lrrr}
\hline \multirow{2}{*}{ Opleidingssector } & \multicolumn{2}{c}{ Niveau door werkgever vereist? } & \multirow{2}{*}{ Verschil in \% } \\
\cline { 2 - 3 } & \multicolumn{1}{c}{ ja } & nee & \\
\hline BOL niv. 1/2 landbouw & 4,27 & 5,09 & -19 \\
BOL niv. 1/2 techniek & 7,27 & 6,82 & 7 \\
BOL niv. 1/2 economie & 7,59 & 6,62 & 15 \\
BOL niv. 1/2 gezondheidszorg & 8,61 & 6,91 & 25 \\
BOL niv. 3/4 landbouw & 7,91 & 7,31 & 8 \\
BOL niv. 3/4 techniek & 9,63 & 9,21 & 5 \\
BOL niv. 3/4 economie & 8,24 & 7,74 & 6 \\
BOL niv. 3/4 gezondheidszorg & 8,85 & 7,52 & 18 \\
BOL niv. 3/4 gedrag en maatschappij & 9,55 & 8,34 & 14 \\
BBL niv. 1/2 landbouw & 8,95 & 7,33 & 22 \\
BBL niv. 1/2 techniek & 8,58 & 8,99 & -4 \\
BBL niv. 1/2 economie & 7,28 & 7,12 & 2 \\
BBL niv. 1/2 gezondheidszorg & 7,53 & 7,30 & 3 \\
BBL niv. 3/4 landbouw & 9,47 & 8,12 & 17 \\
BBL niv. 3/4 techniek & 12,27 & 10,75 & 14 \\
BBL niv. 3/4 economie & 9,50 & 8,17 & 16 \\
BBL niv. 3/4 gezondheidszorg & 11,82 & 9,54 & 24 \\
BBL niv. 3/4 gedrag en maatschappij & 10,30 & 9,32 & 11 \\
Totaal & & & \\
\cline { 1 - 2 } Bron: ROA (RUBS) & 9,20 & 8,36 & 10 \\
\hline
\end{tabular}

Bron: ROA (RUBS) 
De tabel toont dat dit inderdaad het geval is. Gemiddeld genomen levert een goede match tussen opleidings- en baanniveau een ongeveer $10 \%$ hogere beloning op. Tussen de verschillende opleidingssectoren zijn er echter opmerkelijke verschillen. Het effect van een goede match is het grootst voor de zorgopleidingen. BBL'ers niveau 3 en 4 gezondheidszorg die een baan gevonden hebben die goed aanluit bij het opleidingsniveau verdienen bijvoorbeeld bijna $25 \%$ meer dan onderbenutte collega's. Dit is niet verrassend, aangezien het hier vakspecifieke opleidingen betreft. De aansluiting tussen opleiding en beroepspraktijk is daarbij erg belangrijk. De kwaliteit van de aansluiting lijkt er voor BOL'ers niveau 3 en 4 wat minder toe te doen voor BBL'ers. BOL'ers zijn wat breder opgeleid dan BBL'ers en kunnen, ook wanneer de aansluiting niet perfect is, wellicht wat meer een eigen draai geven aan de functie. Ook kan het betekenen dat werkgevers bewust kiezen voor een wat hoger opgeleide in een bepaalde functie. Zij kiezen daarmee voor een schoolverlater die breed inzetbaar is en vanuit een wat mindere startpositie wel een goed carrièreperspectief kan hebben.

Figuur 4.3

Percentage MBO-schoolverlaters dat de laatste vier weken actief op zoek is geweest naar (ander) werk naar opleidingssector, 2001

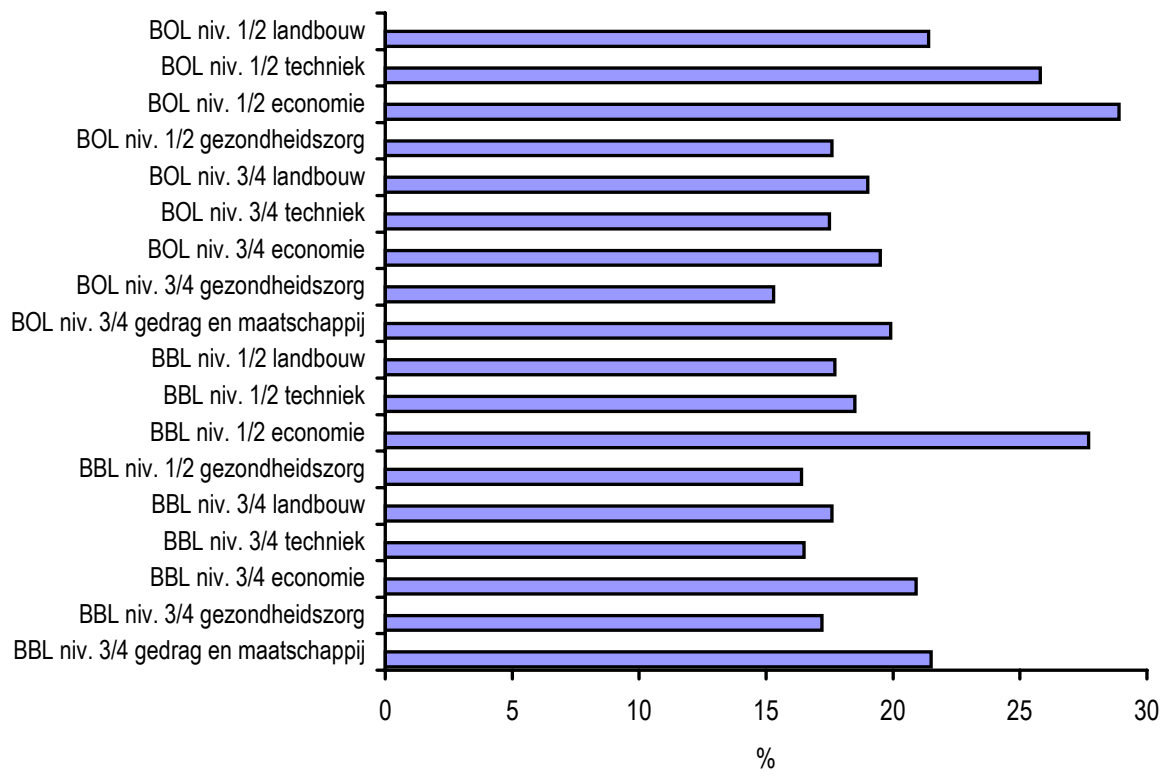

Bron: ROA (RUBS)

\section{Bijna $20 \%$ op zoek naar (ander) werk}

Het al dan niet op zoek zijn naar (ander) werk kan gezien worden als een indicator voor de tevredenheid met de huidige situatie. Het kan hierbij gaan om een MBOschoolverlater, die op dit moment werk heeft, maar (al dan niet gedwongen) op zoek is naar ander werk. Het kan ook een student betreffen die overweegt zijn studie te beëindigen en actief op zoek is naar een baan. Een derde groep vormen uiteraard de werklozen die actief naar werk zoeken. In alle drie gevallen kunnen we spreken van 
MBO-schoolverlaters die niet tevreden zijn met hun huidige situatie en het gevoel hebben niet op hun plek te zitten. Figuur 4.3 geeft een overzicht van het aantal MBOschoolverlaters dat de laatste vier weken actief op zoek naar (ander) werk is geweest. Bijna $20 \%$ antwoordt bevestigend op deze vraag. De tabel laat verder een gevarieerd beeld zien. Het aantal actieve zoekers is bij de schoolverlaters van economische opleidingen op niveau 1 en 2 het grootst (ongeveer 28\%).

\section{Schoolverlaters niveau 3 en 4 over het algemeen tevreden over studiekeuze}

De studiekeuze heeft een belangrijke invloed op de latere (beroeps)loopbaan. Spijt achteraf over de studiekeuze is daarom een tweede belangrijke indicator voor de tevredenheid met de huidige situatie. Werkenden geven hiermee aan dat ze wellicht een andere werkplek voor ogen hebben gehad toen zij aan de studie begonnen. De verder lerende schoolverlater kan spijt hebben van zijn keuze omdat hij niet tevreden is over de afgesloten opleiding en de opleiding die hij nu volgt. Figuur 4.4 laat zien in hoeverre MBO-schoolverlaters achteraf gezien tevreden zijn over de keuze voor de recent afgesloten opleiding. Ruim driekwart van hen zou opnieuw voor dezelfde opleiding kiezen. Er zijn enkele duidelijke verschillen tussen de opleidingssectoren. De schoolverlaters van opleidingen op niveau 3 en 4 zijn het meest tevreden. Over het algemeen is ongeveer $80 \%$ achteraf tevreden met de keuze voor de afgesloten opleiding. Opvallend is dat voor de economische opleidingen op deze niveaus wat lager is; voor de BOL-opleidingen zelfs lager dan 70\%. BOL'ers niveau 1 en 2 zijn het minst vaak tevreden. Ruim $60 \%$ van de BOL'ers landbouw, techniek en economie zou voor dezelfde opleiding kiezen. Van de spijtoptanten geeft ongeveer de helft aan liever een andere opleiding op hetzelfde niveau gevolgd te hebben.

Figuur 4.4

Percentage MBO-schoolverlaters dat de afgesloten opleiding achteraf bezien opnieuw zou volgen naar opleidingssector, 2001

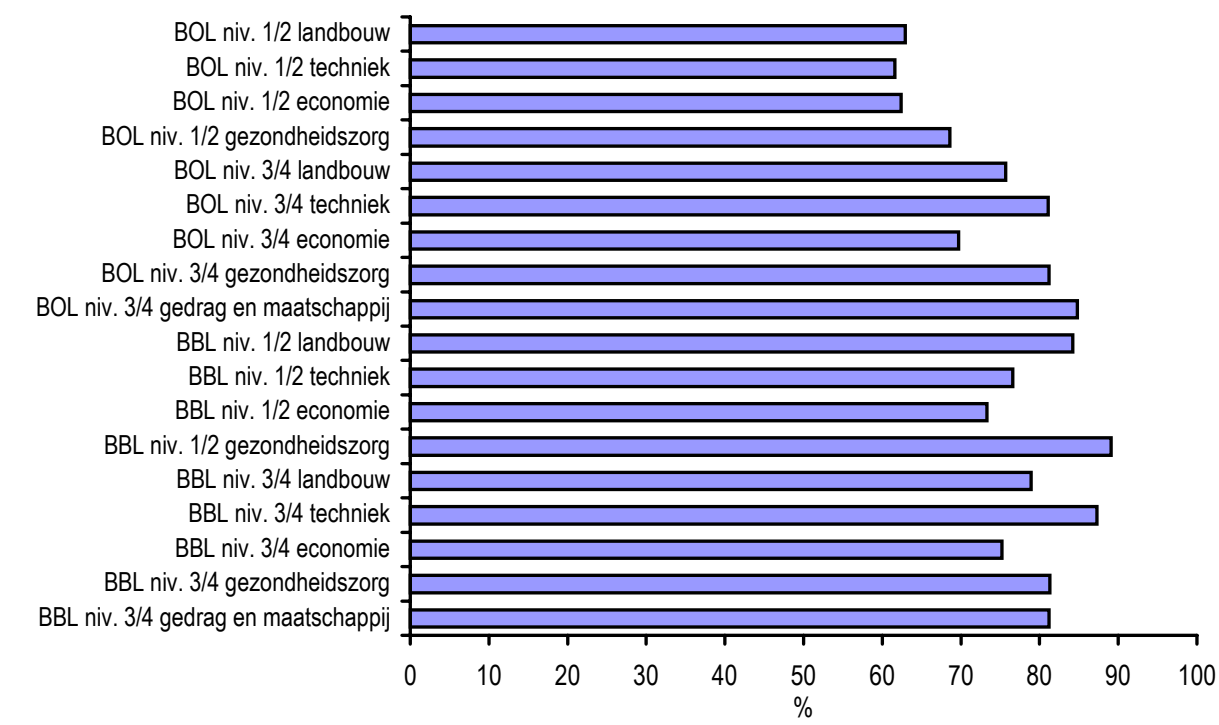

Bron: ROA (RUBS) 



\section{De arbeidsmarkt voor MBO'ers tot 2006}

De voorafgaande hoofdstukken hebben laten zien hoe de arbeidsmarkt voor MBO'ers er momenteel uitziet. Op basis van prognoses met betrekking tot de verwachte vraag- en aanbodontwikkelingen kan een indicatie worden verkregen van de verwachte perspectieven voor schoolverlaters op de Nederlandse arbeidsmarkt, verbijzonderd naar opleiding ${ }^{4}$. Wanneer het verwachte arbeidsaanbod kleiner is dan de verwachte vraag, wordt het arbeidsmarktperspectief als goed of zeer goed bestempeld. Schoolverlaters zullen dan naar verwachting betrekkelijk gemakkelijk een baan vinden op een functieniveau en in een -richting waarop men toen men aan de opleiding begon zou mogen rekenen. In het geval van een matig of slecht arbeidsmarktperspectief zullen schoolverlaters naar verwachting veel moeite hebben om een passende baan te vinden. Zij zullen worden gedwongen een baan in een andere richting of onder hun niveau te accepteren, tegen minder gunstige arbeidsvoorwaarden te werken, meer en langer tijdelijk werk te accepteren of zullen zelfs werkloos worden.

Het zijn echter niet alleen de vraag-aanbodverhoudingen die de arbeidsmarktpositie van een opleiding bepalen. Ook structurele factoren spelen een rol. Deze structurele kenmerken van de arbeidsmarktpositie geven een indicatie van de arbeidsmarktrisico's die de keuze voor een bepaalde opleiding met zich meebrengt. In de eerste plaats komt het arbeidsmarktrisico van een bepaalde opleidingskeuze tot uiting in de mate waarin de werkgelegenheid van degenen met de desbetreffende opleidingsachtergrond onderhevig is aan conjuncturele fluctuaties. Wanneer er sterke schommelingen optreden in de werkgelegenheid voor een bepaalde opleiding, is er voor degenen die voor deze opleiding kiezen op het moment dat het economisch tij gunstig is een risico dat hun arbeidsmarktperspectieven op het moment dat zij hun diploma behalen slecht zijn, omdat de economie dan misschien net in een dal zit. Bovendien is er in dat geval sprake van een onzekere werkgelegenheidssituatie op langere termijn, vanwege de grotere kans op toekomstig baanverlies als er op een gegeven moment weer sprake is van laagconjunctuur.

De risico's op de arbeidsmarkt beperken zich vanzelfsprekend niet tot de conjuncturele fluctuaties in de werkgelegenheid. Ook de mate waarin schoolverlaters afhankelijk zijn van de werkgelegenheidsperspectieven in slechts een beperkt aantal beroepen of bedrijfssectoren is een belangrijke risicofactor. Dit risico is vooral groot bij zogenaamde 'smalle' opleidingen, dat wil zeggen: opleidingen die specifiek gericht zijn op functies in een bepaalde vakdeelmarkt. Degenen die daarentegen een opleiding hebben gevolgd waarmee men in diverse beroepen en bedrijfssectoren

4. Dit hoofdstuk is gebaseerd op een onderzoek dat ROA tweejaarlijks uitvoert. In dit onderzoek staan prognoses met betrekking tot de middenlange termijnontwikkelingen op de Nederlandse arbeidsmarkt centraal. Zie, voor het doel en opzet van deze prognoses en een uitgebreid overzicht van de meest recente verwachtingen, Researchcentrum voor Onderwijs en Arbeidsmarkt (2001), De arbeidsmarkt naar opleiding en beroep tot 2006, ROA-R2001/8, Maastricht. 
emplooi kan vinden, kunnen als het werkgelegenheidsperspectief in een bepaalde beroepsgroep minder gunstig is, betrekkelijk gemakkelijk uitwijken naar beroepen waarvoor de werkgelegenheidsontwikkeling gunstiger is. Bovendien zijn degenen die voor deze zogenaamde 'brede' opleidingen hebben gekozen ook meer flexibel op de arbeidsmarkt wanneer men tijdens de studie- of arbeidsloopbaan meer inzicht krijgt in de persoonlijke capaciteiten en voorkeuren die men heeft, waardoor de beroepsperspectieven die aanvankelijk aanlokkelijk leken, hun aantrekkingskracht verliezen.

Het volgen van een brede opleiding is overigens niet in alle gevallen positief. Wanneer er sprake is van veel uitwijkmogelijkheden impliceert dit immers ook dat de schoolverlaters op de arbeidsmarkt meer concurrentie zullen ondervinden van andere opleidingstypen. Bovendien kan een verbreding van een opleiding ten koste gaan van de specialisatie, waardoor de productiviteit c.q. de directe inzetbaarheid van de schoolverlaters geringer wordt. Dit kan met een lagere beloning gepaard gaan. Het belang van uitwijkmogelijkheden op de arbeidsmarkt moet daarom vooral worden gezien in relatie tot het risico op een niet stabiele werkgelegenheidsontwikkeling.

\section{Technische opleidingen conjunctuurgevoelig}

Tabel 5.1 geeft een overzicht van de MBO-opleidingen met een redelijk tot (zeer) goed arbeidsmarktperspectief ${ }^{5}$. Schoolverlaters van deze opleidingen zullen naar verwachting over het algemeen weinig moeite hebben om een passende baan te vinden. De figuur is verdeeld in vier vlakken. Het vlak rechtsonder heeft betrekking op de opleidingen waarvoor de arbeidsmarktrisico's het grootst zijn. Voor deze opleidingen wordt weliswaar verwacht dat er de komende jaren voldoende vraag zal zijn, zodat de schoolverlaters een passende baan kunnen vinden. Het specialistische karakter en de hoge conjunctuurgevoeligheid maakt opleidingen zoals installatietechniek en procestechniek echter kwetsbaar op de arbeidsmarkt. Het betreft hier met name technische opleidingen die erg afhankelijk zijn van conjunctuurgevoelige bedrijfssectoren zoals de bouw en de chemie. Ook de opleidingen in het vlak linksonder worden gekenmerkt door een hoge conjunctuurgevoeligheid. Zij zijn echter iets minder kwetsbaar, omdat schoolverlaters van deze opleidingen wat breder inzetbaar zijn.

\section{Zorgopgeleiden relatief beperkt inzetbaar}

In het vlak rechtsboven bevinden zich de specialistische opleidingen met een lage conjunctuurgevoeligheid. Het betreft hier vooral zorgopleidingen, zoals verpleging en dokters-, tandarts en dierenartsassistent. Weliswaar is het perspectief goed en zal een conjuncturele neergang niet meteen tot een sterke afname van de vraag naar schoolverlaters leiden, het smalle beroependomein en de afhankelijkheid van de zorg maakt schoolverlaters van deze opleidingen toch enigszins kwetsbaar.

5. De in dit hoofdstuk gebruikte opleidingsindeling wijkt enigszins af van de indeling in de voorgaande hoofdstukken. Bij de prognoses wordt geen onderscheid gemaakt naar niveau en leerweg. Er worden daarentegen meer richtingen onderscheiden. Voor meer informatie, zie Researchcentrum voor Onderwijs en Arbeidsmarkt (2002), ROA-Classificatiegids 2002, ROA-R-2002/3, Maastricht 


\section{Economisch opgeleiden lopen weinig risico}

Het vlak linksboven bevat opleidingen met relatief weinig risico. Een breed scala aan opleidingen is hier terug te vinden. Opvallend is dat de meeste economische opleidingen gekenmerkt worden door lage risico's. Er zal naar verwachting de komende jaren niet alleen genoeg vraag naar schoolverlaters van deze opleidingen. Een conjuncturele neergang zal bovendien een relatief gering effect hebben op deze vraag. Bovendien zijn de verworven kwalificaties inzetbaar in een breed scala aan beroepen op MBO-niveau.

Tabel 5.1

Structurele positie van opleidingen met een redelijk tot (zeer) goed perspectief tot 2006

\section{Weinig risico}

MBO landbouw en veeteelt

$\mathrm{MBO}$ laboratorium

MBO vliegtuigtechniek

$M B O$ verzorging

MBO horeca

MBO administratie

MBO handel

MBO toerisme en recreatie

MBO bedrijfskunde

MBO automatisering

MBO geld, bank en belastingen

MBO openbare orde en veiligheid

\section{Conjunctuurgevoelig, breed inzetbaar}

MBO grond-, weg- en waterbouw

$\mathrm{MBO}$ werktuigbouw en mechanische

techniek

MBO fijnmechanische techniek

MBO elektrotechniek

$\mathrm{MBO}$ vervoer en logistiek

Bron: ROA (POA)

\section{Ongevoelig voor conjunctuur,} beperkt inzetbaar

MBO dokters-, tandarts- en dierenartsassistent MBO apothekersassistent

$\mathrm{MBO}$ verpleging

MBO gezondheidstechniek

MBO secretariaat

$\mathrm{MBO}$ verzekeringswezen

\section{Opleidingen met een ongunstig perspectief}

Tabel 5.2 geeft een overzicht van de MBO-opleidingen met een matig of slecht arbeidsmarktperspectief. Schoolverlaters van deze opleidingen zullen naar verwachting over het algemeen veel moeite hebben om een passende baan te vinden. Opvallend is dat het hier opleidingen betreft die niet conjunctuurgevoelig zijn. De opleidingen milieu en groene ruimte en uiterlijke verzorging hebben een relatief specialistische karakter. Niet alleen schiet de vraag naar verwachting de komende jaren tekort, schoolverlaters hebben bovendien weinig uitwijkmogelijkheden naar andere functies op MBO-niveau. Voor de opleidingen links in de tabel zijn de uitwijkmogelijkheden groter. Weliswaar zullen schoolverlaters van bijvoorbeeld grafische en sociaal-culturele opleidingen moeite hebben een passende baan te vinden, 
de door hen verworven kwalificaties zijn breder inzetbaar op de arbeidsmarkt. Dit biedt hen de mogelijkheid ook buiten het eigen domein een functie te verwerven.

Tabel 5.2

Structurele positie van opleidingen met een matig tot slecht perspectief tot 2006

\section{Weinig risico}

MBO grafische techniek

MBO brood en banket

MBO levensmiddelentechniekvleesverwerking

MBO sociaal-cultureel

MBO beweging en therapie

\section{Conjunctuurgevoelig, breed inzetbaar}

Bron: ROA (POA)
Ongevoelig voor conjunctuur, beperkt inzetbaar

MBO milieu en groene ruimte

MBO uiterlijke verzorging
Veel risico 


\section{Bijlage: niveaus en leerwegen in het MBO}

Sinds 1 januari 1996 is de Wet Educatie en Beroepsonderwijs (WEB) van kracht waarin een nieuwe kwalificatiestructuur voor het middelbaar beroepsonderwijs is vastgelegd. In het onderstaande schema wordt een overzicht gegeven van de relatie tussen de oude en de nieuwe kwalificatiestructuur. Belangrijkste kenmerken van de nieuwe structuur zijn de vier onderscheiden niveaus en het feit dat deze niveaus leerweg-neutraal zijn. Dat wil zeggen dat een opleiding voor alle niveaus in principe via twee leerwegen gevolgd kan worden. Allereerst is dat de beroepsopleidende leerweg $(B O L)$ die vergelijkbaar is met het oude MBO-dagonderwijs. Daarnaast is dat de beroepsbegeleidende leerweg $(B B L)$ waarbij minimaal $60 \%$ van de studieduur uit praktijkvorming bestaat. Deze leerweg is te vergelijken met het 'werkend leren' in het oude leerlingwezen (LLW).

Vergelijking oude en nieuwe kwalificatiestructuur volgens de WEB

\begin{tabular}{|c|c|c|c|c|}
\hline Niveau & $\begin{array}{l}\text { Nieuwe } \\
\text { opleidingsaanduiding }\end{array}$ & $\begin{array}{l}\text { Opleidingsaanduiding } \\
\text { Agrarische sector }\end{array}$ & $\begin{array}{l}\text { Oude } \\
\text { opleidingsaanduiding }\end{array}$ & Duur \\
\hline 1 & Assistentenopleiding & $\begin{array}{l}\text { Assisterend } \\
\text { beroepsbeoefenaar }\end{array}$ & - & $\begin{array}{l}0,5-1 \\
\text { jaar }\end{array}$ \\
\hline 2 & Basisberoepsopleiding & $\begin{array}{l}\text { Beginnend } \\
\text { beroepsbeoefenaar }\end{array}$ & $\begin{array}{l}\text { MBO-kort } \\
\text { LLW -primair }\end{array}$ & $\begin{array}{l}2-3 \\
\text { jaar }\end{array}$ \\
\hline 3 & Vakopleiding & $\begin{array}{l}\text { Zelfstandig } \\
\text { beroepsbeoefenaar }\end{array}$ & $\begin{array}{l}\text { MBO-tussen } \\
\text { MBO-lang } \\
\text { LLW-secundair }\end{array}$ & $\begin{array}{l}2-4 \\
\text { jaar }\end{array}$ \\
\hline 4 & Middenkaderopleiding & Kaderfunctionaris & $\begin{array}{l}\text { MBO-lang } \\
\text { LLW-tertiair }\end{array}$ & $\begin{array}{l}3-4 \\
\text { jaar }\end{array}$ \\
\hline 4 & Specialistenopleiding & $\begin{array}{l}\text { Gespecialiseerd } \\
\text { beroepsbeoefenaar }\end{array}$ & LLW-tertiair & $\begin{array}{l}1-2 \\
\text { jaar }\end{array}$ \\
\hline
\end{tabular}

Bron: LDC 
